\title{
Molecular Distinction Among Mulberry (Morus Spp.) Species and Varieties Cultivated in DPR Korea
}

Un-Hyang Ho ( $\sim$ uh.ho@ryongnamsan.edu.kp)

Kim II Sung University

Jung Sam Kye

Kim II Sung University

Song Im Chae

Kim II Sung University

Jong Ho Kim

Academy of Agricultural Sciences

Myong Ho Kim

Kim II Sung University

\section{Short Report}

Keywords: mulberry, ISSR, molecular distinction, species, variety

Posted Date: June 7th, 2021

DOI: https://doi.org/10.21203/rs.3.rs-482675/v1

License: (c) (i) This work is licensed under a Creative Commons Attribution 4.0 International License. Read Full License 


\section{Abstract}

Mulberry (Morus spp.) is a cross-pollinating and highly hybridized plant of which productivity are greatly varied in different varieties. We analysed molecular distinction among four mulberry species and varieties cultivated in DPR Korea by using nuclear ribosomal internal transcribed spacer (ITS) sequences and inter simple sequence repeat (ISSR) markers. ITS sequences didn't represent a remarkable interspecific distinction among four mulberry species used in our study, suggesting that it could not be employed to identify them. ISSR analysis using 16 random primers generated 158 different markers ranging from 100 to $4000 \mathrm{bp}$ in size. The results showed the inter-specific genetic variation (55.34\%) was slightly higher than intra-specific genetic variation(44.66\%), with comparatively low average number of migrants per generation ( $\mathrm{Nm}$ ) among populations (0.3886). Using ISSR primers selected in this study, in the future, the suitable breeding strategy might be established in raising of elite mulberry varieties on the basis of interspecific hybridization.

\section{Introduction}

Mulberry (Morus spp.) is a cross-pollinating and highly hybridized plant belonging to the genus Morus, which is widely distributed in nature, having been evolved by natural crossing, artificial hybridization and mutation.

Mulberry is a sole food plant, of which productivity is varied in different varieties with the intraspecific distinction value of $169.8 \%$ in the early years of the last century (1928-1930), whereas $253.5 \%$ in recent years (2013-2019). Therefore, the importance of elite mulberry varieties for high silk cocoon and mulberry leaf production is much higher than any cultivation conditions. Hence, it is substantial to reorder collectively and classify more scientifically many culticvated mulberry varieties in order to produce a large number of new varieties by using good resources efficiently and subsequently to contribute to the silk cocoon production.

The genus Morus, which is widely distributed in tropical, sub-tropical and tempereate regions, is cultivated extensively in East, Central and South Asia such as DPR Korea, China, Vietnam and Thai for silk production. The genus Morus has 68 recognised species including M. mongolica Schneid., M. bombycis Koidz., M. alba Linn., M. multicaulis Perr., M. nigra L., M. rubra L., M. tartarica L., M. indica L., M. papyrifera and M. tinctoria (Sanjappa, 1989).

In DPR Korea M. mongolica Schneid. is cultivated in mountainous areas of South and North Phyongan provinces, north Hamgyong province, Kangwon Province, Jagang Province and it exhibits high cold tolerance, having remarkablely long style $(1 \sim 2 \mathrm{~mm})$ in female flowers.

M. bombycis Koidz. is grew naturally in the mountains and fields of DPR Korea, China and Japan, being dioecious or androgynous and having similarly long style $(1 \sim 2 \mathrm{~mm})$ like $M$. mongolica Schneid.

M. alba Linn. is most widely distributed in the world such as DPR Korea, China (Chang, 1984), Vietnam (Chang, 1984; Kansumata, 1973), India (Dhar and Ahsan, 1989; Ravindran et al., 1997) and Japan (Maichii, 1999), and is a only cultivar in European countries. This species is dioecious or androgynous and the style in female flowers is absent or indistinct.

M. multicaulis Perr. is originated from China and has been cultivated during many years in DPR Korea. It is dioecious and shown only female plants in DPR Korea with a very short style $(0.2 \mathrm{~mm})$. 
So far, using morphological and biochemical characters (Mala et al., 1998; Fotedar and Dandin, 1998; Vijayan et al., 1999; Tikader and Roy, 2001) there were many reports to classify mulberry species and cultivars, but these methods were time consuming and even might be made a mistake because of environmental variation.

Generally, the classification of mulberry is performed by comparing some morphological traits such as floral characters. For example, the length of catkins $(4.1 \sim 7.2 \mathrm{~cm}$ in some varieties while $1.7 \sim 2.4 \mathrm{~cm}$ in other varieties) (Das et al., 1970; Tikader et al., 1995) and the style length in female flowers and the nature of stigma in male flowers (1 $2 \mathrm{~mm}$ in M. mongolica Schneid. and M. bombycis Koidz. wheras absent or $0.2 \sim 0.5 \mathrm{~mm}$ in $M$. alba Linn. and M. multicaulis Perr.) (Koidzumi, 1917). But such floral characters are greatly changed depending on environmental conditions including temperature, day length and daylight, and cultivating conditions such as hormonal application or pruning of branches of the plant (Das and Mukherjee, 1992).

As above mentioned, in mulberry floral characters could not be utilized to identify species and cultivars as an only diagnostic marker. Especially, it is difficult to identify species and cultivars in highly hybridized plants like mulberry. So it is critical to use not only morphological and biochemical traits but also molecular markers to solve disruptions in species, cultivation classification and identification.

Additionally, using molecular markers the accurate classification is important in the breeding of a cross pollinating mulberry plant. Because the cross hybridization between mulberry species represent a high seed fertility (Das and Krishnaswami, 1965; Dandin et al., 1987), the interspecific crossing is favor to mulberry breeding to increase leaf yield potential.

Earlier studies have been focused on elucidation of genetic distinction among mulberry species and varieties by

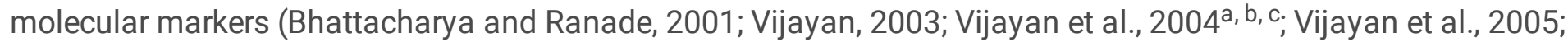
Vijayan et al., 2006; Kar et al., 2008).

There were reports on phylogenetic relationship between a little number of local indian genotypes using ISSR markers(Vijayan and Chatterjee, 2003), eleven species of M. alba L. by ISSR and RAPD technique (Prem et al., 2004), and Chinese wild and cultivated mulberry cultivars based on ISSR and SSR markers (Zhao et al., 2006, $2007^{a}$, b). By employing RAPD markers, the work has been also performed to reveal genetic relationship among some mulberry genotypes (Bhattacharya and Ranade, 2001; Chatterjee et al., 2003; Muzaffer et al., 2012; Nataraj and Chikkaswamy 2017). And recently, there were attempts to solve the problems remaining in the classificational identification of mulberry species based on RAPD and ISSR markers (Chikkaswamy and Rabin Chandra, 2014; Girish Naik et al., 2015; Rita et al., 2016).

Besides, ITS sequence has been used as a potential nuclear DNA marker to discriminate each other on the level of species in most plants (Walker and David, 2012). Recent study revealed that the nuclear ribosomal ITS sequence was more efficient than the chloroplastic $p s b A$-trnH sequence in differentiating medicinal plant Boerhavia diffusa from other Boerhavia species (Dhivya et al., 2012). So far, there have been some attempts to use ITS sequences for phylogenetic classification and evolutionary research (Zhao et al., 2005; Zeng et al, 2015; Yahui et al., 2019).

This study aimed to elucidate genetic distinction among four mulberry species such as $M$. mongolica Schneid., $M$. bombycis Koidz., M. alba Linn. and M. multicaulis Perr., including fourteen varieties by using ITS sequence and ISSR markers. 
Variable sites of ITS seuennces differing in species level among 4 mulbery species used in our study were not found and it shows that ITS sequences can't be used to classify these mulberry species.

ITS sequences didn't show a considerable distinction among four studied mulberry species, indicating that it could not be applied to classify mulberry species.

In M. multicaulis Perr. the highest ISSR polymorphism (31.62\%) and observed number of alleles (1.34), the highest effective number of alleles (1.27), Shanon's index (0.21) and Nei's gene diversity (0.15) were founded. Nei's

genetic distance is the most genetically close between M. mongolica Schneid. and M. bombycis Koidz. (0.1377), while the most distant between M. bombycis Koidz. and M. multicaulis Perr. (0.3244). ISSR results showed that inter-specific genetic variation (55.34\%) is somewhat higher than intra-specific genetic variation(44.66\%), with relatively low average number of migrants per generation $(\mathrm{Nm})$ among populations $(0.3886)$.

This result suggests that ISSR markers might be superior to ITS sequences to distinct diffrent species as well as mulberry varieties used in this study.

Depending on the genetic distinction among fourteen mulberry varieties cultivated in DPR Korea obtained in this study, in the future the selection of more suitable crossing pairs will be conducted to expect a disirable hybrid vigor in the breeding of a highly heterozygous mulberry plant.

\section{Materials And Methods}

\subsection{Plant material}

We used four species, fourteen mulberry varieties cultivated in DPR Korea as the experiment samples (Table 1).

Table 1 Characteristics of mulberry varieties used in this study 


\begin{tabular}{|c|c|c|c|c|c|}
\hline No & Variety & $\begin{array}{l}\text { Style } \\
\text { length/mm }\end{array}$ & $\begin{array}{l}\text { the fruit of the mulberry } \\
/ \mathrm{mm} \times \mathrm{mm}\end{array}$ & $\begin{array}{l}\text { Country of } \\
\text { origin }\end{array}$ & Species \\
\hline 1 & "Sunchon" & $1.5 \sim 2.0$ & $15 \times 10$ black & DPR Korea & \multirow{2}{*}{$\begin{array}{l}\text { M. mongolica } \\
\text { Schneid. }\end{array}$} \\
\hline 2 & "Jasan" & $1.5 \sim 2.0$ & $15 \times 10$ black & DPR Korea & \\
\hline 4 & "Cha1" & $0.8 \sim 1.0$ & $10 \times 10$ red or black & DPR Korea & \multirow{4}{*}{$\begin{array}{l}\text { M. bombycis } \\
\text { Koidz. }\end{array}$} \\
\hline 3 & "Gomji" & 1.0 & $14 \times 10$ black & DPR Korea & \\
\hline 5 & "Huichon" & $1.5 \sim 2.0$ & $15 \times 10$ black and red & DPR Korea & \\
\hline 6 & "Sariwon1" & 1.2 & $15 \times 10$ black & DPR Korea & \\
\hline 7 & "Jam1" & 0.1 & $14 \times 9$ white & Russia & \multirow[t]{4}{*}{ M. alba Linn. } \\
\hline 8 & "Dongrim10" & 0.2 & 14 16×11 9 black & DPR Korea & \\
\hline 9 & "Dongrim316" & $0.1 \sim 0.2$ & & Japan & \\
\hline 10 & "Ryongchon" & $0.1 \sim 0.2$ & $12 \times 8$ black & DPR Korea & \\
\hline 11 & "Ropong" & $0.2 \mathrm{~mm}$ & $26 \times 10$ black & DPR Korea & \multirow[t]{4}{*}{ M. multicaulis Perr. } \\
\hline 12 & "Horo" & Absent & & China & \\
\hline 13 & "Huangro" & Absent & $10 \times 8$ black & China & \\
\hline 14 & "Sariwon2" & Absent & & DPR Korea & \\
\hline
\end{tabular}

\subsection{Genomic DNA extraction}

Genomic DNA was extracted from $100 \mathrm{mg}$ of fresh leaf material modifying CTAB method (Cetyl Trimethyl Ammonium Bromide) developed by Doyle \& Doyle (1990). In this method the concentration of CTAB was raised up to $3 \%$ because of mulberry leaves contain high contents of carbohydrates and polyphenols.

\subsection{Assessment of DNA quality}

DNA quality was measured by using Nanodrop Spectrophotometer (Thermoscientific Nanodrop 1000, USA) and subsquently performed electrophoresis through $1 \%$ agarose gel using 1 X TAE buffer at $80 \mathrm{~V}$ for 40 mins.

\subsection{Sequencing of nuclear ribosomal ITS sequences}

ITS1, 5.8S, ITS2 sequences were amplified using ITS5/ITS4 primers (F: GGAAGTAAAAGTCGTAACAAGG, R: TCCTCCGCTTATTGATATGC), with genomic DNA from fourteen mulberry varieties as a temple (White et al., 1990).

PCR products were loaded onto 1.5\% agarose gel for electrophoresis followed by purification using Qiagen's PCR mini-prep kit and DNA sequencing by Sanger dideoxy method.

Using MEGA 5.05, we aligned common regions (576bp) of the sequences from 14 mulbery species and 26 sequences (M. alba L.: AY345157, AY345148, AY345149, FJ599759, FJ917003, FJ980402, HM747164, HQ144172, HQ144173, HQ144174, JN115037, JN407491, M. mongolica Schneid.: AY345158, AB604250, AB604256, AB604264, AB604266, AB604268, AB604273, M. multicaulis Perr.: AY345153, AM042003, M. bombycis.Koidz: AY345151, AB604246, AB604254, AB604270, AB604282) registered to NCBI data base and analysed for their similarity. 
On the basis of above aligning results, we tested the existence of ITSSNP pattern shared by individuals of same species to assess whether ITS sequences could be used to species distinction of mulberry. In case there exist a few indels peculiar to some registed sequencs (AY345157, AY345149, AY345158, AY345151, AY345153), we thought these are endemic to ecological type of the species and excluded from analysis.

\subsection{ISSR analysis}

According to the protocol described by Gulab et al., (2018), PCR was performed in a $20 \mu$ l reaction volume containing $2 \mu \mathrm{l}$ of $10 \mathrm{X}$ Taq buffer, $2 \mu$ l of dNTPs, $2 \mu \mathrm{L}$ of $\mathrm{MgCl}_{2}, 1 \mu \mathrm{l}$ of primer, $0.1 \mu \mathrm{L} 0.1 \mathrm{U} / \mu \mathrm{L}$ Taq polymerase, $1 \mu \mathrm{l}$ of temple DNA $(100 \mathrm{ng} / \mu \mathrm{l})$ and $11.9 \mu \mathrm{l}$ of $\mathrm{ddH}_{2} \mathrm{O}$ for each sample in a Mastercycler (nexus gradient).

After 80 from ISSR primer set (UBC = University of British Columbia) on two individuals were tested for each of the four mulberry species, and we selected 16 primers (Table 3) with both reproducible and polymorphic variation with well defined and darkly staining bands.

PCR programme in Mastercycler (nexus gradient) was as follows; an initial denaturation step of $94^{\circ} \mathrm{C}$ for 5 min, followed by 30 cycles of $30 \mathrm{~s}$ at $94^{\circ} \mathrm{C}, 45 \mathrm{~s}$ at $50^{\circ} \mathrm{C}$ and 2 min at $72^{\circ} \mathrm{C}$, a final extension step of $72^{\circ} \mathrm{C}$ for $5 \mathrm{~min}$.

PCR products were separated on 1.2\% agarose gels in $1 \times$ TAE buffer at $80 \mathrm{~V}$ for 40 mins, subsquent staining gels with ethidium bromide and being taken photographs under UV light by using Geldoc-It ${ }^{\mathrm{TM}}$ (USA).

\subsection{Data analysis}

To analyse the genetic distinction among mulberry varieties, Nei' s genetic distances were calculated, and a dendrogram was constructed using the unweighted paired group method of cluster analysis using arithmetic averages (UPGMA) and obtained PCA plots with NTSYSpc version 2.20 (Rohlf, 2008).

The POPGENE ver. 1.32 (Yeh et al., 2000) was used to estimate values meaning genetic diversity: number of polymorphic band, observed number of alleles, effective number of alleles (Kimura and Crow 1964), Nei's (1973) gene diversity (h), Shannon's information index (I) (Lewontin 1972) and also, $\mathrm{G}_{\mathrm{ST}}$ representing population differentiation and gene flow (Nm) among populations were estimated.

Analysis of molecular variance (AMOVA) was performed to evaluate the distribution of genetic variation within and among mulberry speices using the Arlequin ver. 3.5. (Excoffier \& Lischer, 2010).

\section{Results And Discussion}

\subsection{Assessment of the potential to classify four mulberry species using ITS sequences}

We sequenced the nuclear ribosomal ITS1, 5.8S rRNA, and ITS2 sequences and examined whether they were utilized to classify four mulberry species (Table 1 ). 
Table 2

Multiple alignment of ITS sequences from 14 mulbery cultivars and previously accessed ones. (Sites indicated in the Table are variable sites differing from comon sequence, Arabial numbers from 1 to 14 represent the number of each cultivar listed in Table 1.)

\begin{tabular}{|c|c|c|c|c|c|c|c|c|c|c|c|}
\hline Species & $\begin{array}{l}\text { Accession } \\
\text { number }\end{array}$ & 18 & 93 & 114 & 121 & 169 & 546 & 562 & 570 & 571 & 572 \\
\hline \multirow[t]{13}{*}{ M. alba Linn. } & AY345148 & $A$ & $\mathrm{C}$ & $\mathrm{C}$ & $\mathrm{C}$ & $\mathrm{T}$ & C & $\mathrm{T}$ & $\mathrm{C}$ & $\mathrm{T}$ & $\mathrm{C}$ \\
\hline & FJ599759 & . & . & . & . & . & . & . & . & . & . \\
\hline & FJ917003 & . & . & . & . & . & . & . & $\mathrm{T}$ & $\mathrm{C}$ & $\mathrm{T}$ \\
\hline & FJ980402 & . & . & . & . & . & . & . & . & . & . \\
\hline & HM747164 & . & . & . & . & . & . & . & . & . & . \\
\hline & HQ144172 & . & . & . & . & . & . & . & . & . & . \\
\hline & HQ144173 & G & . & . & . & . & $\mathrm{T}$ & . & . & . & . \\
\hline & HQ144174 & . & . & . & . & . & . & . & . & . & . \\
\hline & JN115037 & . & . & . & . & . & . & . & . & . & . \\
\hline & JN407491 & . & . & . & . & . & . & . & . & . & . \\
\hline & 8 & . & . & . & . & . & . & . & . & . & . \\
\hline & 9 & . & . & . & . & . & . & . & . & . & . \\
\hline & 10 & . & . & . & . & . & . & . & . & . & . \\
\hline \multirow{9}{*}{$\begin{array}{l}\text { M. mongolica. } \\
\text { Schneid. }\end{array}$} & AB604250 & . & . & . & . & . & . & . & . & . & . \\
\hline & AB604256 & . & . & . & . & . & . & . & . & . & . \\
\hline & AB604264 & . & . & . & . & . & . & . & . & . & . \\
\hline & AB604266 & . & . & . & . & . & . & . & . & . & . \\
\hline & AB604268 & . & . & . & . & . & . & . & . & . & . \\
\hline & AB604273 & . & . & . & . & . & . & . & . & . & . \\
\hline & 1 & . & . & . & . & . & . & . & . & . & . \\
\hline & 2 & . & . & . & . & . & . & . & . & . & . \\
\hline & 4 & . & . & . & . & . & . & $\mathrm{G}$ & . & . & . \\
\hline \multirow[t]{5}{*}{ M. multicaulis Perr. } & AM042003 & . & . & . & . & . & . & . & . & . & . \\
\hline & 11 & . & . & . & . & . & . & . & . & . & . \\
\hline & 12 & . & . & . & . & . & . & . & . & . & . \\
\hline & 13 & . & . & . & . & . & . & . & . & . & . \\
\hline & 14 & . & . & . & . & . & . & . & . & . & . \\
\hline M. bombycis.Koidz. & AB604246 & . & $\mathrm{G}$ & G & $\mathrm{T}$ & $A$ & . & . & . & . & . \\
\hline
\end{tabular}




\begin{tabular}{|c|c|c|c|c|c|c|c|c|c|c|c|}
\hline Species & $\begin{array}{l}\text { Accession } \\
\text { number }\end{array}$ & 18 & 93 & 114 & 121 & 169 & 546 & 562 & 570 & 571 & 572 \\
\hline & AB604254 & . & . & . & . & . & . & . & . & . & . \\
\hline & AB604270 & . & . & . & . & . & . & . & . & . & . \\
\hline & AB604282 & . & . & . & . & . & . & . & . & . & . \\
\hline & 3 & . & . & . & . & . & . & . & . & . & . \\
\hline & 5 & . & . & . & . & . & . & . & . & . & . \\
\hline & 6 & . & G & G & $\mathrm{T}$ & $A$ & . & . & . & . & . \\
\hline & 7 & . & . & . & . & . & . & . & . & . & . \\
\hline
\end{tabular}

In general, ITS sequence has been used as a potential nuclear DNA marker for phylogenetic classification and evolutionary research (Zhao et al., 2005; Walker and David, 2012; Zeng et al, 2015; Yahui et al., 2019), because it was more efficient than the chloroplastic sequences in identifying different species (Dhivya et al., 2012).

Zhao et al., (2005) constructed the phylogenetic tree of 9 mulbery species using ITS sequences and reported its usefulness for species identification. Zeng et al., (2015) identified 8 mulbery species species in genus Morus based on ITS sequences. Yahui et al., (2019) reconstructed phylogenetic tree of mulbery species considering pseudogenes existing in ITS sequences.As shown in Table 2, species specific distinction of ITS sequences among 4 mulbery species, M. alba Linn., M. mongolica Schneid., M. multicaulis Perr., M. bombycis.Koidz., was not found. The SNPs peculiar to 5 sequences (FJ917003, HQ144173, No 4, AB604246, No 6) were not species specific.

This suggests that a universal marker for species identification in most plants, ITS sequences (Walker and David, 2012; Dhivya et al., 2012) might not applied to 4 mulberry species used in this study.

\subsection{Molecular distinction among mulberry species and varieties by ISSR analysis}

Here we analysed the genetic relationship among and within mulberry speies were analysed by 16 informative ISSR primers (Table 3, Fig. 1). 
Table 3

Primers used for ISSR analysis, total number of scored fragments and their size range

\begin{tabular}{|c|c|c|c|c|}
\hline No & Primer & $\begin{array}{l}\text { Sequence } \\
\left(5^{\prime} \rightarrow 3^{\prime}\right)\end{array}$ & $\begin{array}{l}\text { Fragment size } \\
\text { range (bp) }\end{array}$ & $\begin{array}{l}\text { Total number } \\
\text { of bands }\end{array}$ \\
\hline 1 & UBC807 & $(\mathrm{AG})_{8} \mathrm{~T}$ & $100 \rrbracket 2000$ & 10 \\
\hline 2 & UBC808 & $(A G)_{8} C$ & $100 \sim 1500$ & 13 \\
\hline 3 & UBC810 & $(\mathrm{GA})_{8} \mathrm{~T}$ & $200 \sim 3000$ & 9 \\
\hline 4 & UBC811 & $(\mathrm{GA})_{8} \mathrm{C}$ & $300 \rrbracket 2000$ & 10 \\
\hline 5 & UBC812 & $(\mathrm{GA})_{8} \mathrm{~A}$ & $200 \sim 3000$ & 10 \\
\hline 6 & UBC823 & $(\mathrm{TC})_{8} \mathrm{C}$ & $100 \sim 2000$ & 9 \\
\hline 7 & UBC825 & $(\mathrm{AC})_{8} \mathrm{~T}$ & $500 \sim 4000$ & 10 \\
\hline 8 & UBC827 & $(A C)_{8} G$ & $250 \sim 3000$ & 8 \\
\hline 9 & UBC830 & $(\mathrm{TG})_{8} \mathrm{G}$ & $100 \sim 4000$ & 9 \\
\hline 10 & UBC834 & $(\mathrm{AG})_{8} \mathrm{YT}$ & $100 \varangle 2000$ & 11 \\
\hline 11 & UBC841 & $(G A)_{8} Y C$ & $100 \rrbracket 4000$ & 10 \\
\hline 12 & UBC844 & $(\mathrm{CT})_{8} \mathrm{RC}$ & $250 \sim 3000$ & 9 \\
\hline 13 & UBC845 & $(\mathrm{CT})_{8} \mathrm{RG}$ & $300 \sim 4000$ & 9 \\
\hline 14 & UBC852 & $(\mathrm{TC})_{8} \mathrm{RA}$ & $100 \sim 3000$ & 9 \\
\hline 15 & UBC853 & $(\mathrm{TC})_{8} \mathrm{RT}$ & $500 \varangle 3000$ & 10 \\
\hline 16 & UBC854 & $(\mathrm{TC})_{8} \mathrm{RG}$ & $200 \sim 4000$ & 12 \\
\hline
\end{tabular}

ISSR analysis using 16 random primers generated 158 different markers ranging from 100 to 4000 bp in size. Fifty four of these were polymorphic (94.9\%) over all studied genotypes, with an average of 9.88 markers per primer.

Lines marked by numbers $(1,2,3 \ldots, 14)$ represent the individuals that belong to varieties listed in Table $1 . M-1 \mathrm{~kb}$ ladder

The genetic distinction among 14 mulberry varieties was evaluated using NTSYSpc2.11 on the basis of ISSR profiles. 
Table 4

Genetic distance between 14 studied mulberry varieties

\begin{tabular}{|c|c|c|c|c|c|c|c|c|c|c|c|c|c|c|}
\hline & 1 & 2 & 3 & 4 & 5 & 6 & 7 & 8 & 9 & 10 & 11 & 12 & 13 & 14 \\
\hline 1 & 0 & & & & & & & & & & & & & \\
\hline 2 & 0.09 & 0 & & & & & & & & & & & & \\
\hline 3 & 0.14 & 0.15 & 0 & & & & & & & & & & & \\
\hline 4 & 0.14 & 0.16 & 0.12 & 0 & & & & & & & & & & \\
\hline 5 & 0.21 & 0.18 & 0.15 & 0.23 & 0 & & & & & & & & & \\
\hline 6 & 0.19 & 0.20 & 0.04 & 0.16 & 0.11 & 0 & & & & & & & & \\
\hline 7 & 0.24 & 0.17 & 0.26 & 0.15 & 0.21 & 0.26 & 0 & & & & & & & \\
\hline 8 & 0.23 & 0.20 & 0.25 & 0.21 & 0.27 & 0.25 & 0.11 & 0 & & & & & & \\
\hline 9 & 0.29 & 0.21 & 0.30 & 0.21 & 0.24 & 0.26 & 0.08 & 0.10 & 0 & & & & & \\
\hline 10 & 0.19 & 0.21 & 0.30 & 0.26 & 0.28 & 0.30 & 0.12 & 0.10 & 0.14 & 0 & & & & \\
\hline 11 & 0.29 & 0.25 & 0.30 & 0.21 & 0.33 & 0.30 & 0.19 & 0.21 & 0.22 & 0.27 & 0 & & & \\
\hline 12 & 0.29 & 0.25 & 0.30 & 0.18 & 0.37 & 0.30 & 0.12 & 0.21 & 0.18 & 0.18 & 0.07 & 0 & & \\
\hline 13 & 0.35 & 0.26 & 0.32 & 0.22 & 0.29 & 0.27 & 0.24 & 0.26 & 0.28 & 0.37 & 0.15 & 0.19 & 0 & \\
\hline 14 & 0.35 & 0.31 & 0.42 & 0.23 & 0.34 & 0.37 & 0.17 & 0.23 & 0.16 & 0.20 & 0.16 & 0.16 & 0.21 & 0 \\
\hline
\end{tabular}

After obtaining data matrix (Table 4) based on Nei (1973)'s genetic distance, we constructed a dendrogram showing genetic relatedness of all studied mulberry varieties using UPGMA method.

As shown in Fig. 2 and Fig. 3, at genetic distance of 0.186, the dendrogram grouped all varieties in three main clusters. First cluster comprised of No. 1, 2, 4 varieties (M. mongolica Schneid.), and No. 3, 6, 5 varieties ( $M$. bombycis Koidz.). Second cluster contained No. 7, 9, 8, 10 varieties (M. alba Linn.), and final third cluster involved No. 11, 12, 14, 13 varieties (M. multicaulis Perr.). The genetic distance among all fourteen varieties varied from 0.04 (between "Gomji" and "Sariwon 1") to 0.37 (between "Sariwon 1" and "Sariwon 3", "Ryongchon" and "Huangro") with average value of 0.22 .

Based on the genetic distances between fourteen varieties, we anlaysed genetic relationship among four species using PopGene.version 1.31. 
Table 5

Nei's (1978) genetic distance among four studied mulberry species.

\begin{tabular}{|lllll|}
\hline & $\begin{array}{l}\text { M. mongolica } \\
\text { Schneid. }\end{array}$ & $\begin{array}{l}\text { M. bombycis } \\
\text { Koidz. }\end{array}$ & $\begin{array}{l}\text { M. alba } \\
\text { Linn. }\end{array}$ & $\begin{array}{l}\text { M. multicaulis } \\
\text { Perr. }\end{array}$ \\
\hline $\begin{array}{l}\text { M. mongolica } \\
\text { Schneid. }\end{array}$ & $*$ & 0.8714 & 0.8249 & 0.8144 \\
\hline $\begin{array}{l}\text { M. bombycis Koidz. } \\
\text { M. alba Linn. }\end{array}$ & 0.1377 & $*$ & 0.7792 & 0.7229 \\
\hline $\begin{array}{l}\text { M. multicaulis Perr. } \\
\text { Nei's genetic identity (above diagonal) and genetic distance (below diagonal). }\end{array}$ & 0.1925 & 0.2494 & 0.8158 \\
\hline
\end{tabular}

And we analysed genetic differentiation among four mulberry species using PopGene.version 1.31.

Table 6

Genetic diversity indices for four mulberry varieties. $\mathrm{N}_{\mathrm{PB}^{-}}$number of polymorphic bands, $\mathrm{P}_{\mathrm{PB}^{-}}$ percentage of polymorphic bands, $\mathrm{n}_{\mathrm{a}}$ - observed number of alleles, $\mathrm{n}_{\mathrm{e}}$-effective number of alleles, h - Nei's (1987) gene diversity, I - Shannon's information index

\begin{tabular}{|lcccccc|}
\hline Species & $\mathbf{N}_{\mathrm{PB}}$ & $\mathbf{P}_{\mathrm{PB}}$ & $\mathbf{n}_{\mathbf{a}}$ & $\mathbf{n}_{\mathbf{e}}$ & $\mathbf{h}$ & $\mathrm{I}$ \\
\hline Morus mongolicac.K. Schneid & 34 & 25.00 & $1.25 \pm 0.44$ & $1.15 \pm 0.30$ & 0.09 & 0.21 \\
\hline Morus bombycis.Koidz & 25 & 18.38 & $1.18 \pm 0.39$ & $1.10 \pm 0.24$ & 0.06 & 0.10 \\
\hline Morus alba. Linn & 34 & 25.00 & $1.25 \pm 0.44$ & $1.19 \pm 0.36$ & 0.11 & 0.15 \\
\hline Morus multicaulis perr & 43 & 31.62 & $1.34 \pm 0.48$ & $1.27 \pm 0.40$ & 0.15 & 0.21 \\
\hline
\end{tabular}

We obtained a mean Gst value of 0.5627 for 4 mulberry species (ranging from 0.0803 to 0.8290 ) and an average number of migrants per generation ( $\mathrm{Nm}$ ) among populations of 0.3886 (in the range of 0.1031 and 5.7241 ).

Finally, we performed AMOVA to estimate genetic differentiation among 14 mulberry varieties cultivatied in DPR Korea using Arlequin ver. 3.5.2.2.

Table 7

Molecular analysis of variance (AMOVA) based on ISSR profiless in four mulberry species

\begin{tabular}{|c|c|c|c|c|c|c|}
\hline $\begin{array}{l}\text { Source of } \\
\text { variation }\end{array}$ & $\begin{array}{l}\text { degrees of } \\
\text { freedom }\end{array}$ & $\begin{array}{l}\text { Sum of } \\
\text { squares }\end{array}$ & $\begin{array}{l}\text { Variance } \\
\text { components }\end{array}$ & $\begin{array}{l}\text { Percentage of } \\
\text { variation (\%) }\end{array}$ & $\mathbf{P}$ & $\begin{array}{l}\text { Fixation } \\
\text { Indices }\end{array}$ \\
\hline $\begin{array}{l}\text { Among } \\
\text { species }\end{array}$ & 3 & 204.881 & $3.51667 \mathrm{Va}$ & 55.34 & $\begin{array}{l}\mathrm{P}< \\
0.0002\end{array}$ & $\begin{array}{l}F_{C T} \\
0.45345\end{array}$ \\
\hline $\begin{array}{l}\text { Within } \\
\text { species }\end{array}$ & 10 & 175.833 & $2.91758 \mathrm{Vb}$ & 44.66 & $\begin{array}{l}P< \\
0.0002\end{array}$ & $F_{S C} 1.0000$ \\
\hline Total & 13 & 385.714 & 6.43425 & & & \\
\hline
\end{tabular}

As shown in Table 7, of the total genetic diversity, $55.34 \%$ was attributable to differences among species and $44.66 \%$ was to differences between varieties, showing higher interspecific differentiation than varietal differentiation. 
ISSR or RAPD technique has been utilized in elucidation of genetic distinction among mulberry species and varieties.

In previous studies, 8 RAPD primers produced 67 discrete bands varied from 300 to 1000 bp showing $93.1 \%$ polymorphism among 14 mulberry genotypes (Rita et al., 2016), 16 primers generated 61 polymorphic bands of 75 bands ranging from 300 to 5000 bp showing over 18 mulberry cultivars with an average of 4.6 markers per primer (Chikkaswamy and Rabin, 2014). And Shivashankar (2015) obtained 41 of 45 amplication products (94\% polymorphism) with 300-5000 bp in size, confirming the tendency similar with our results.

In Prem et al. (2004)'s study on M. alba Linn., the genetic similarity was in the range of 0.738 for China whitw and Kattaneo to 0.909 for Sujanpur-2 and Punjab local with a average of 0.834 , suggesting the tendency similar to our results.

As shown Table 5 and Fig. 4, the group of M. mongolica Schneid. was the most genetically close to the group of $M$. bombycis Koidz. (genetic distance- 0.1377 ), and the latter was the most genetically distant to the group of M. multicaulis Perr. (genetic distance- 0. 3244), reflecting somewhat their geographic origin. Our results show similar tendency with the genetic similarity coefficient among M. alba Linn., M. bombycis Koidz., and $M$. multicaulis Perr. species in Awasthi (2004)' study (M. alba Linn. and M. multicaulis Perr.: $0.573>M$. alba L. and $M$. bombycis Koidz. : 0.405, M. bombycis Koidz. and M. multicaulis Perr. : 0.385).

In Prem et al. (2004)'s study on white mulberry species, Indian genotypes made a distant group with the Japanese, indicating the availability of Japanese genotypes in the genetic improvement of Indian white mulberry geneotypes. Similarly, in our work M. mongolica Schneid. and M. bombycis Koidz. resulted in a distant group with M. alba L. and M. multicaulis Perr., suggesting the possibility of cross hybridization between these species in the breeding of elite mulberry varieties.

In this study, the highest ISSR polymorphism (31.62\%) and observed number of alleles (1.34), the highest effective number of alleles (1.27), Shanon's index (0.21) and Nei's gene diversity (0.15) were obtained for $M$. multicaulis Perr. population (Table 6). Based on Nei's genetic distances, the most genetically close pair is $M$. mongolica Schneid. and M. bombycis Koidz. (0.1377), whereas the most distant one is - M. bombycis Koidz. and M. multicaulis Perr. (0.3244). The results showed the low intra-specific genetic variation (44.34\%) and the slight high inter-specific genetic variation (55.66\%).

In Zhenjiang et al., (2016)' study evaluating genetic relationship among 42 mulberry genotypes from seven countries over Asia and South America using 17 inter simple sequence repeat (ISSR) primers, the average Nei's index and Shanon's information index were 0.116 and 0.174 , respectively, showing low diversity of mulberry. This exhibits a similar tendency with the results on M. alba L. (Nei's index-0.11, Shanon's information index-0.15) in our study.

\section{Conclusions}

M. mongolica Schneid., M. bombycis Koidz., M. alba L. and M. multicaulis Perr. used in this study are cultivated extensively for sericulture in DPR Korea, are differentiated from each other based on the style length in female flowers. But this character can be changed according to environmental and cultivational conditions, the identification of mulberry species and varieties depending on only this character likely cause a mistake in

Page 12/18 
establishing breeding strategy of a cross pollinating mulberry plant. But ITS sequence commonly used for species identification in most plants can not be applied to mulberry species owing to the deficiency of interspecific distinction.

Therefore, the genetic relationship among fourteen mulberry varieties cultivated in DPR Korea obtained in this study, will be contributed to the selection of more suitable crossing pairs in the breeding of a highly heterozygous mulberry plant expecting a disirable hybrid vigor.

\section{Declarations}

The authors have no relevant financial or non-financial interests to disclose.

The authors have no conflicts of interest to declare that are relevant to the content of this article.

All authors certify that they have no affiliations with or involvement in any organization or entity with any financial interest or non-financial interest in the subject matter or materials discussed in this manuscript.

The authors have no financial or proprietary interests in any material discussed in this article.

\section{Acknowledgements}

We thank all researchers of Sericultural Research institute, Academy of Agricultural Sciences who helped mulberry sample collection.

\section{References}

1. Awasthi Arvind K, Nagaraja GM, Naik GV, Kanginakudru Sriramana, Thangavelu K and Nagaraju Javaregowda (2004) Genetic diversity and relationships in mulberry (genus Morus) as revealed by RAPD and ISSR marker assays. BMC Genetics 5: 1

2. Bhattacharya $E$ and Ranade SA (2001) Molecular distinction amongst the varieties of Mulberry using RAPD and DAMD profiles. BMC Plant Biology. 3 (available from http://www.biomed central. com/1471-2229/1/3)

3. Chang S S (1984) New taxa of Moraceae from China and Vitnam. Acta Phytotax Stn 22: 64-76

4. Chatterjee SN, Nagaraja GM, Srivastava PP, Naik GY (2003) Morphological and molecular variation of Moruslaevigata in India. Genetica 121: 133-143

5. Chikkaswamy B K and Rabin Chandra paramanik (2014) An investigation of RAPD and ISSR molecular marker studies in Mulberry varieties. International Journal of Current Microbiology and Applied Sciences 3(6): 986-995

6. Dandin S B, Kumar R, Rabindran S and Jolly M S (1987) Crossability studies in mulberry. Indian Journal of Sericulture 24: 1-4

7. Das B C and Krishnaswami S (1965) Some observations on interspecific hybridization in mulberry. Indian Journal of Sericulture 4: 1-4

8. Das BC, Prasad DN and Krishnaswami S (1970) Studies on anthesis in mulberry. Indian Journal of Sericulture 9: $59-63$ 
9. Das BK and Mukherjee SK (1992) Modification of sex expression in mulberry by colchicines- $B$, a potent antigibberllin. Indian Journal of Sericulture 31: 173-175

10. Dhar A and Ahsan M M (1989) Mulberry species and their distribution in North-western Himalayas, in Genetic resources of mulberry and its utilization, edited by K Sengupta and S B Dandin (Central Sericultural Research and Training Institute, Mysore, India), 111-124

11. Dhivya Selvaraj, Dhivya Shanmughanandhan, Rajeev Kumar Sarma, Jijo C Joseph, Ramachandran V Srinivasan and Sathishkumar Ramalingam (2012) DNA Barcode ITS Effectively Distinguishes the Medicinal Plant Boerhavia diffusa from Its Adulterants. Genomics Proteomics Bioinformatics 10: 364-367

12. Doyle JJ and Doyle JL (1990) Isolation of plant DNA from fresh tissue. Focus 12: 13-15

13. Excoffier L and Lischer HEL (2010) Arlequin suite ver 3.5: a new series of programs to perform population genetics analyses under Linux and Windows. Molecular Ecology Resources 10: 564-567

14. Fotedar R K and Dandin S B (1998) Genetic divergence in the mulberry. Sericologia 38: 115-125

15. Girish Naik V, Dandin S B and Tikader A (2015) Marian Vincent Pinto, Molecular diversity of wild mulberry (Morus spp.) of Indian subcontinent. Indian Journal of Biotechnology 14: 334-343

16. Gulab Khan Rohela, Phanikanth Jogam, Aftab Ahmad Shabnam, Pawan Shukla, Sadanandam Abbagani and Mrinal Kanti Ghosh (2018) In vitro regeneration and assessment of genetic fidelity of acclimated plantlets by using ISSR markers in PPR-1 (Morus sp.): An economically important plant. Scientia Horticulturae 241: 313321

17. Kansumata F (1973) Mulberry species in South Vietnam. J. Seric. Sci. JPN. 42: 84-88

18. Kar PS, Srivastava PP, Awasthi AK and Raje Urs S (2008) Genetic variability and association of ISSR markers with some biochemical traits in mulberry (Morus spp.) genetic resources available India. Tree Genetics \& Genomes 4: 75-83

19. Kimura M and Crow J F (1964) The number of alleles that can be maintained in a finite population. Genetics 49: 725-738

20. Koidzumi G (1917) Taxonomical discussion on Morus plants. Bull. Imp. Sericult. Exp. Stat. 3: 1-62

21. Lewontin RC (1972) The apportionment of human diversity. Evolutionary Biology 6: 381-398

22. Maichii H, Koyama A and Yamanouchi H (1999) A list of genetic mulberry resources maintained at National Institute of Sericulture and Entomological Sciences. Misc. Publ. Natl. Seric. Entomol. Sci. (Japan) 26: 1-77

23. Mala V R, Chaturvedi H K and Sarkar A (1998) Multivariate analysis as an aid to accession selection for breeding in mulberry. Indian Journal of Sericulture 36: 111-115

24. Muzaffer 'Ipek L "utfi Pirlak and Salih Kafkas (2012) Molecular characterization of mulberry (Morus spp.) genotypes via RAPD and ISSR. Journal of the Science of Food and Agriculture 92: 1633-1637

25. Nataraj K and Chikkaswamy .B K (2017) Computer Application of Ward's method for RAPD analysis of mulberry varieties. International Journal of Scientific \& Engineering Research 8(5): 77-92

26. Nei M (1973) Analysis of gene diversity in subdivided populations. Proceedings of the National Academy of Sciences of the United States of America 70: 3321-3323

27. Prem P Srivastava, Kunjupillai Vijayan, Aravind K. Awasthi and Beera Saratchandra (2004) Genetic analysis of Morus alba through RAPD and ISSR markers. Indian Journal of Biotechnology 3: 527-532

28. Ravindran S, Rao A A, Naik V G, Tikader A, Mukherjee P and Thangavelu K (1997) Distribution and variation in mulberry germplasm. Indian Journal of Plant Genetic Resources 10: 233-242 
29. Rita Banerjee, Chattopadhyay S and Saha A K (2016) Genetic Diversity and Relationship of Mulberry Genotypes Revealed by RAPD and ISSR Markers. Journal of Crop Improvement 30(4): 478-492

30. Rohlf F J (2008) NTSYSpc: Numerical taxonomy system, ver. 2.20. Exerter Publishing Ltd., Setauket, New York

31. Sanjappa M (1989) Geographical distribution of and exploration of genus Morus L. (Moraceae), in Genetic resources of mulberry and its utilization, edited by K Sengupta \& S B Dandin (Central Seriucltural Research and Training Institute, Mysore, India), 4-8

32. Shivashankar M (2015) Study on RAPD Molecular Distinction in Mulberry Varieties. International Journal of Current Microbiology and Applied Sciences 4(4): 1097-1105

33. Tikader A and Roy B N (2001) Multivariate analysis in some mulberry (Morus spp.) germplasm accessions. Indian Journal of Sericulture. 40: 168-170

34. Vijayan K (2003) Genetic relationships of Japanese and Indian mulberry (Morus spp.) genotypes revealed by DNA fingerprinting. Plant Systematics and Evolution 243: 221-232

35. Vijayan K and Chatterjee S N (2003) ISSR profiling of Indian cultivars of mulberry (Morus spp.) and its relevance to breeding programs. Euphytica 131: 53-63

36. Vijayan K, Das K K, Doss S G, Chakraborti S P and Roy B N (1999) Genetic divergence in indigenous mulberry (Morus spp.) accessions. Indian Journal of Agricultural Sciences 69: 851-853

37. Vijayan K, Nair CV and Chatterjee SN (2005) Molecular characterization of mulberry genetic resources indigenous to India. Genetic Resources and Crop Evolution 52: 77-86

38. Vijayan K, Tikader A, Kar P K, Srivastava P P, Awasthi A K and Thangavelu K (2006) Assessment of genetic relationships between wild and cultivated mulberry (Morus) species using PCR based markers. Genetic Resources and Crop Evolution 53: 873-882

39. Vijayan Ka , Awasthi AK, Srivastava PP and Saratchandra B (2004) Genetic analysis of Indian mulberry varieties through molecular markers. Hereditas 141: 8-14

40. Vijayan $\mathrm{K}^{\mathrm{b}}$, Srivastava PP and Awasthi AK (2004) Analysis of phylogenetic relationship among five mulberry (Morus) species using molecular markers. Genome 47: 439-448

41. Vijayan KC, Tikader A, Kar PK, Srivastava PP, Awasthi AK, Thangavelu K et al (2004) Molecular evaluation of genetic variability in wild populations of mulberry (Morus serrata Roxb.). Plant Breeding 123: 568-572

42. Walker John Kress and David L Erickson (2012) DNA Barcodes Methods and Protocols. Springer New York Dordrecht Heidelberg London, 379-394

43. White T, Bruns T, Lee S and Taylor J (1990) Amplification and direct sequencing of fungal ribosomal RNA genes for phylogenetics. In: Innis, M., Gelfand, D., Sninsky, J., White, T. (eds) PCR Protocols: a guide to methods and applications. Academic, New York, 315-322

44. Yahui Xuan, Yue Wu, Peng Li, Ruiling Liu, Yiwei Luo, Jianglian Yuan, Zhon ghuai Xiang and Ningjia He (2019) Molecular phylogeny of mulberries reconstructed from ITS and two cpDNA sequences. PeerJ 7: e8158 DOI 10.7717/peerj.8158

45. Yeh FC, Boyle T, Yang R-C and Ye ZMJX (2000) POPGENE, version 1.32. Department of Renewable Resources, University of Alberta, Edmonton, AB, Canada. http://www.Ualberta.ca/ fyeh/ Accessed 5 Oct 2007

46. Zeng QW, Chen HY, Zhang C, Han MJ, Li T, Qi XW, Xiang ZH and He NJ (2015) Definition of eight mulberry species in the genus Morus by internal transcribed spacer-based phylogeny. PLOS ONE 10(8): e0135411 DOI

Page 15/18 
10.1371/journal.pone.0135411

47. Zhao Weiguo, Pan Yile, Zhang Zhifang Jia Shihai, Miao Xuexia and Huang Yongping (2005) Phylogeny of the genus Morus (Urticales: Moraceae) inferred from ITS and trnL-F sequences. African Journal of Biotechnology 4 (6): 563-569

48. Zhao W, Zhou ZH, Miao XX, Wang Lin Zhang SB, Pan YL and Huang YP (2006) Genetic relatedness among cultivated and wild mulberry (Moraceae: Morus) as revealed by inter-simple sequence repeat (ISSR) analysis in China. Canadian Journal of Plant Science 86: 251-257

49. Zhao Wa, Wang Y, Chen T, Jia G, Wang X and Qi J et al (2007) Genetic structure of mulberry from different ecotypes revealed by ISSRs in China: implications for conservation of local mulberry varieties. Scientia Horticulturae. 115: 47-55

50. Zhao W' W $^{\mathrm{b}}$ Zhihua Z, Xuexia Z, Yong M, Sibao Z, Jianhua W et al (2007) A comparison of genetic variation among wild and cultivated Morus species (Moraceae: Morus) as revealed by ISSR and SSR markers.

Biodiversity and Conservation 16: 275-290

51. Zhenjiang Wang, Yufei Zhang, Fanwei Dai, Guoqing Luo, Gengsheng Xiao and Cuiming Tang (2016) Genetic diversity among mulberry genotypes from seven countries. Physiology and Molecular Biology of Plants 23(2): 421-427

\section{Figures}

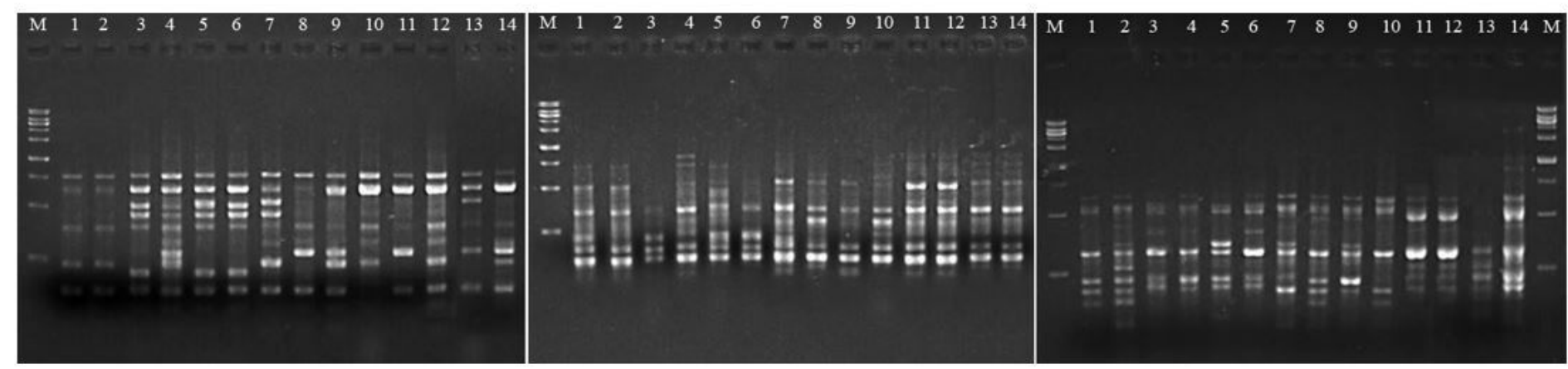

\section{Figure 1}

ISSR agarose gel electrophoresis profiles of fourteen mulberry varieties using UBC808 (left), UBC823 (middle) and UBC834 (right) primers. 
1. Sunchon

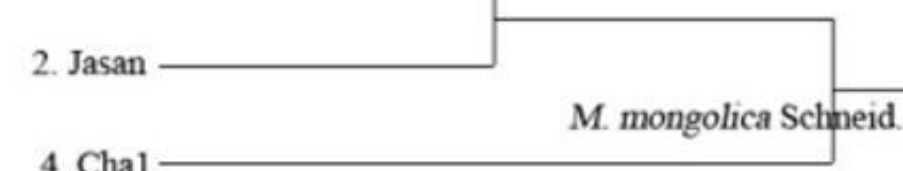

4. Chal

M. mongolica Schneid.

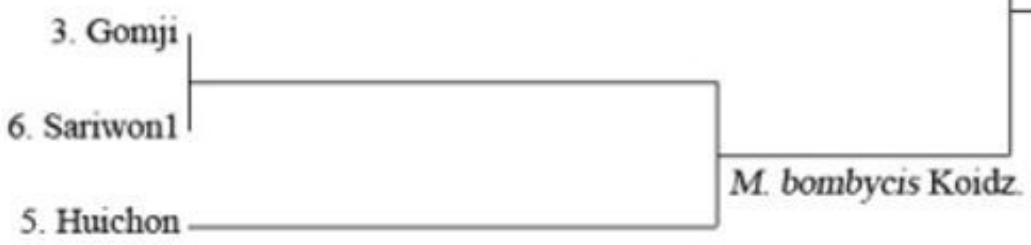

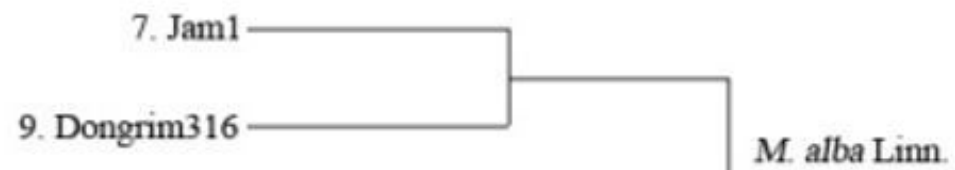

8. Dongrim10 Ryongchon

11. Ropong

12. Horo

14. Sariwon2

M. alba Linn.

13. Huangro

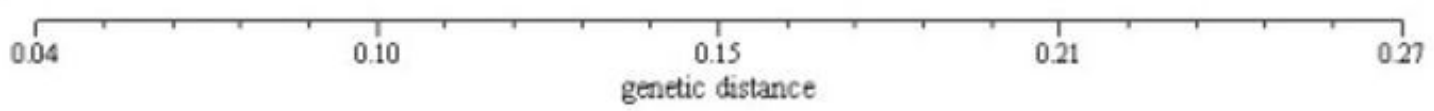

Figure 2

UPGMA dendrogram illustrating the genetic relatedness between fourteen mulberry varieties based on Nei's genetic distance 

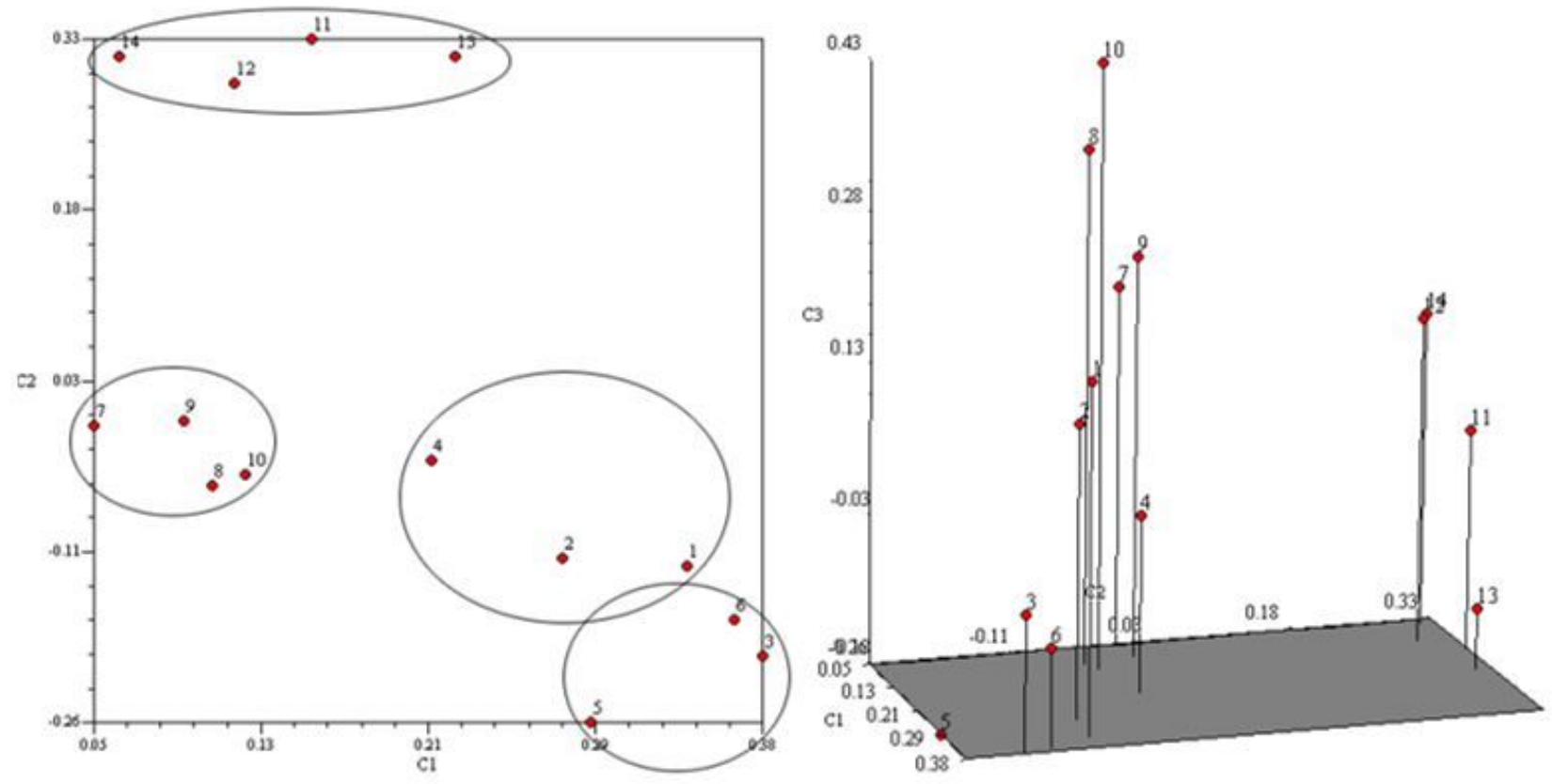

Figure 3

2-D(left) and 3-D(right) PCA plot based on ISSR data in mulberry varieties.

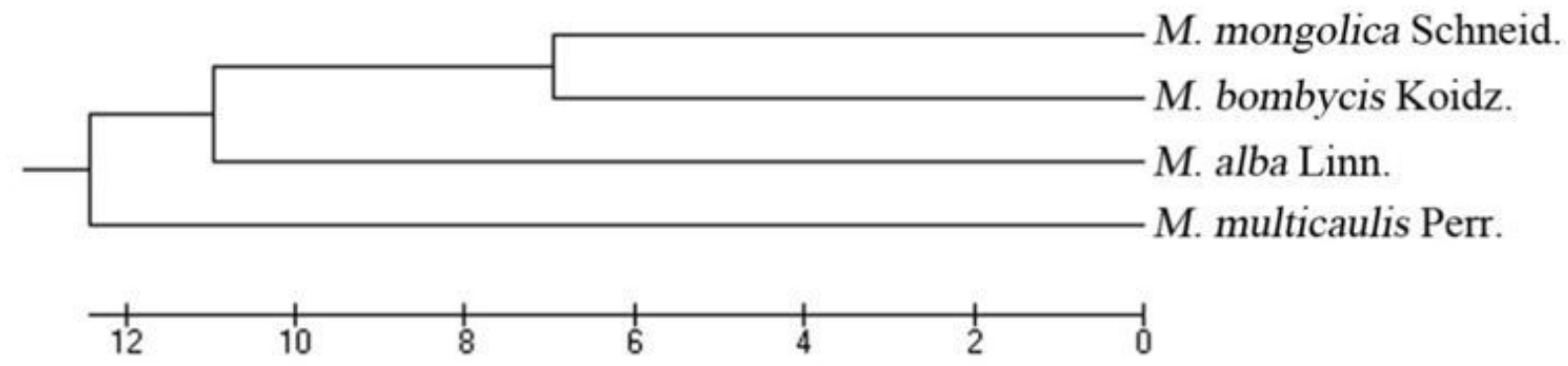

Figure 4

UPGMA dendrogram illustrating the genetic relationships between four mulberry varieties based on Nei's genetic distance 